\title{
STRATEGIES OF NEGATIVE POLITENESS IN JORDANIAN AND AMERICAN ACADEMIC DISCOURSES
}

\author{
Hashem Hani Shehadeh Alhaded ${ }^{1 *}$, Aurika Shavtikova ${ }^{2}$ \\ ${ }^{1}$ Ass.Prof, PhD, RUDN-university, Russian Federation, hashem_1256@hotmail.com \\ ${ }^{2}$ RUDN-university, Russian Federation, aurika.shavtikova.99@mail.ru \\ ${ }^{*}$ Corresponding Author
}

\begin{abstract}
The Middle East is a delicate matter, and the Arab society is of great interest for linguists, since the study of the Arab national style of communication and the factors that shape it, as well as Arab cultural values and strategies of distancing in the Arab-Muslim communicative culture leads to the establishment of intercultural communication and overcoming the problems of communicative linguocultural interference. Recently, in scientific research works, we can observe a tendency to analyze the verbal and non-verbal national-cultural characteristics of the behavior of Arabs, however, there is still a large number of unexplored aspects that complicate the process of intercultural communication. The aim of this paper is to examine strategies for distancing in Jordanian and American academic discourses. The material for the study is based on data that has been conducted from detailed questionnaires in Arabic and in English languages from American and Jordanian university students aged 22 to 35 years. To analyze the speech acts of American and Jordanian students and professors, we used the theory of negative politeness proposed by P. Brown and S. Levinson. On the basis of this theory, we have identified and defined the strategies of negative politeness used in the academic discourses of two cultures - American and Jordanian. The results of the work showed that the theory of P. Brown and S. Levinson about negative politeness can be applied to analyze not only the American academic discourse, but also for the Jordanian academic discourse, taking into account the specific cultural characteristics of the Arabs. Moreover, the results can be used in teaching Arabic as a foreign language, as well as in works that deal with negative politeness within the American and Arabic academic discourses.
\end{abstract}

Keywords: negative politeness, strategies of negative politeness, Arabic language, academic discourse.

\section{INTRODUCTION}

In the modern world, research in the field of pragmatics has acquired great importance. In connection with the expansion of intercultural contacts, studies in the field of politeness have gained popularity. The study of the principles, strategies of politeness, as the most important category of communicative consciousness, is a line of research that is widespread in the modern world of globalization and the development of intercultural relations and connections. However, most of the research in this area was conducted on the example of Western cultures. A large body of fundamental work examines the strategies and principles of politeness in these particular cultures. Here we can cite the Theory of politeness by P. Brown and S. Levinson, set out in the work "Politeness: some universals in language usage" $(1978,1987)[5]$, "Principles of Pragmatics" by J. Leach (1977) [10], where he identified six maxims of polite communication, formulated by P. Grice in his work "Logic and Speech Communication" [6] The Principle of Cooperation, which includes four maxims that are realized in the process of communication. As for Russian linguistics, we can mention such authors as M.V. Volodin, S.I. Gorbachevskaya, E.A. Zatsepina, L. Kastler, T.V. Larina [2], I.A. Romanova, S.A. 
Risinson. There are also comparative studies that reveal differences in courtesy strategies. Today there is no single view of the theory of politeness. However, it can be stated that the strategies and principles of politeness in different cultures, as well as the ways of expressing it, include an element of universality, but they also have certain differences.

This paper attempts to examine the strategies of negative politeness in Jordanian and American academic discourses. It should be noted that studies conducted in the field of the theory of politeness in conjunction with Arab culture are few and consider this problem in general terms, there are no developed theories of Arabic politeness. The purpose of the study is to trace how the politeness strategies formulated by P. Brown and S. Levinson are implemented in the Arab communicative culture.

\section{BROWN AND LEVINSON'S THEORY OF POLITENESS}

Since in this paper we rely on the theory of politeness by Brown and Levinson, explained and presented in the book "Politeness: some universals on language usage", it is necessary to consider the main provisions of this theory [2].

Despite criticism of this work for its focus on the Western model of communication, it remains the theoretical basis for many cross-cultural studies. The main concept of this theory is the concept of "face" - a universal concept that is a kind of social image, in the preservation of which every member of society is interested. The authors of the theory argue that in the process of communication, the goal of the participants is to preserve the "face", not only their own, but also the interlocutor. This concept was first introduced by the American sociologist Erving Goffman. There are two main parts in this concept: Positive Face and the Negative Face.

A positive face is an image that communicants claim in the course of speech interaction: "The want of every member that his wants to be desirable to at least some others".

A negative face - the desire of every adult to have freedom of action, the inadmissibility of interference from others: "The want of every competent adult member that his actions be unimpeded by others".

A negative face is a kind of "territory"and belongs to E. Goffman. This term, borrowed from ethology, in sociolinguistics means the speaker's personal space, his time, "shell" (body and clothing), property, as well as information (or, in other words, cognitive) space, that is, the totality of thoughts, feelings, information, which the individual possesses.

In real communication, there are many speech acts that called - "Face Threatening Acts". They are divided into four types, depending on "what person" they threaten:

1. To a positive person of the speaker (apology, acceptance of a compliment, recognition, non-control of actions, etc.);

2. To a negative person of the speaker (expression of gratitude, justification, acceptance of the proposal, etc.);

3. To a positive person of the listener (expression of disapproval, contradiction or disagreement, disrespect, mention of taboo topics, etc.);

4. To a negative person listening (orders and requests, suggestions and advice, threats, warnings, challenges, compliments, etc.).

Acts that "threaten" the face are a natural and important part of communication. According to P. Brown and $S$. Levinson, it is necessary to use a variety of strategies to minimize the "threat" to the interlocutor.

The authors introduce such concepts as Positive Politeness and Negative Politeness, which have the opposite direction. Each of these types of politeness is a system of communication strategies with the help of which the main goals of polite communication are achieved. The first is based on approach-based, the second on avoidance-based. Positive politeness is associated with the linguistic expression of solidarity, the inclusion of the interlocutor and other persons in the same group with the speaker, while negative politeness is associated with self-restraint of the speakers, the desire to avoid conflicts.

Demonstrating solidarity and maintaining a distance are the essence of polite behavior, that is, you can be polite if you show your interlocutor your solidarity and at the same time maintain a certain distance. When engaging in dialogue, it is necessary to bring the interlocutor closer using strategies of positive politeness. But at the same time, you cannot violate the personal space of the interlocutor. Negative courtesy strategies are used to demonstrate mutual respect and independence. According to the authors of the theory, negative politeness is more significant and obvious than positive politeness. 
Intimacy and distancing are politeness hyperstrategies used to achieve the most common communication goals. In order to achieve these goals, it is necessary to use a set of speech tactics that have ethnocultural characteristics and depend on the type of culture and pragmatic communication conventions adopted in a particular society: if solidarity is valued in communication, the speaker chooses the tactics of positive politeness, if the emphasis is on respect for the independence of the interlocutor - the tactics of negative politeness

Different types of strategies are associated with different speech acts. For example, strategies of positive politeness, which are aimed at bringing the interlocutors closer, are primarily associated with expressives, the main function of which is to express the speaker's attitude to what is happening (greeting, gratitude, appreciation, compliment, etc.). Strategies of negative politeness, the main goal of which is to demonstrate respect for the personal autonomy of the addressee, are primarily associated with incentive speech acts in which the speaker exerts communicative pressure on the interlocutor.

P. Brown and S. Levinson recognize that politeness can have cultural differences, however, they focus more on the universal side of this phenomenon.

\section{MATERIAL AND RESEARCH METHODOLOGY}

The category of politeness exists in all cultures, including Arabic culture, but how it is realized in a particular language and which strategies the communicants use - this aspect has not been sufficiently researched. In this part of the study, we set the task of finding which distancing strategies of negative politeness are used in Jordanian and American academic discourses, how these strategies are similar and how they differ. The study has been conducted on the base of Brown and Levinson's theory of politeness that is oriented for English language, that allow us to analyze American academic discourse and clarify key features of Jordanian academic discourse in compare with American academic discourse and maintain strategies of negative politeness of Jordanian academic discourse. Our research is based on the answers of respondents: 10 respondents from America and 10 respondents from Jordan. The questionnaire that was given to respondents is consist of three parts:

1. A responder chooses the way of addressing university teacher in different contexts (e.g. in a classroom, in an e-mail, in a coffee shop, etc.).

2. A responder writes down what his/her teacher would normally say in the suggested situations (e.g. classmates making some noise during the lecture, eating something in class, your teacher wants you to open the window, etc.)

3. A responder should answer for the social oriented questions connected to academic discourse (e.g. Do you treat your teachers as equals? What do you consider inappropriate and impolite in students' interaction with teachers? What mode of teacher's behavior do you consider impolite?)

We have collected the answers and analyzed through the theory of negative politeness of Brown and Levinson. During the research we were faced with the following tasks:

1. See how negative politeness strategies are being implemented in the American and Jordanian academic discourses.

2. Correlate specific statements with strategies of distancing.

3. To establish whether it is possible to apply these strategies in the Jordanian communicative culture, thereby determining whether they are universal.

4. In the absence of universality, identify the cultural characteristics characteristic of Jordanian culture and its academic discourse.

In the course of the study, we used a comparative method and pragmatic analysis. We analyzed strategies of negative politeness in American and Jordanian academic discourses using comparing between them and taking in consideration cultural specifics.

\section{NEGATIVE POLITENESS AND STRATEGIES OF DISTANCING IN THE AMERICAN AND JORDANIAN ACADEMIC DISCOURSES: RESULTS OF THE RESEARCH AND DISCUSSION}

After analyzing the language material obtained during the questioning of American and Jordanian students, we found the following examples of how strategies of distancing are reflected: 


\section{Be conventionally indirect}

The strategy of distancing in American academic discourse. Students should write down his or her answer for the following situation:

You didn't understand from the material what was explained in class, you want your teacher to explain it to you after class.

Answer of an American student:

1. Excuse me do you mind us going over the previous topic again at your earliest convenience

In this answer we see that an American student use strategy "be conventionally indirect" by using words excuse me, do you mind us. This example shows the usage the strategy "be conventionally indirect" from student's side, but the same strategy uses a professor in the frame of American academic discourse. Here is the example of this:

It is stuffy in the classroom. Your teacher wants you to open the window.

2. Can the person sitting by the window open it please, thank you.

A professor uses not the direct form - "open the door", but we see that in the American academic discourse professors use strategy "be conventionally indirect". It should be mentioned that the second example shows us the usage of negative politeness and strategies of distancing in requesting something.

Also the same strategy is used in an another way of requesting - when a student can deny the request of the professor. We included to the questionnaire the following situation:

One of your classmates failed to write the test. The teacher wants you to work with him after classes.

We have got the following answer from American student:

3. Mr. Smith would need your help for next exam, would you be able to offer him some of your time to go over the exam material with him?

As we see, professor describes first of all the situation naming a student by title + last name (Mr. Smith) then using the strategy "be conventionally indirect" asks with the form of the question - would you be able. As we see it is a request from a teacher, but a student that is asked to help to another can reject this request. This is an example of this strategy - give $\mathrm{H}$ the option not to do the act.

In the Arabic academic discourse strategies of distancing "be conventionally indirect" is used in the following way:

$$
\text { ما يمكنك سماع ما قاله معلمك بوضوح اثناء الثرح ونود أن يعيد. }
$$

you did not hear what you teacher had said. Ask him to repeat it.

$$
\text { ممكن اعادة هذه النقطة لم أفههها. }
$$

May you repeat it, please, I did not hear.

As we see a student use approximately the same way of strategy "be conventionally indirect" in the Jordanian academic discourse as in the American academic discourse.

Furthermore, strategy of negative politeness in Jordanian academic discourse is used by teachers and professors also:

$$
\text { يطلب منك المعلم كتابة الجواب على السبورة }
$$

Your professor asks to write something of the class-board.

$$
\text { أطلع اكتب الجواب اذا سمحت للطلاب }
$$

Please, go and write the answer for all students.

Here we should discuss the difference of using strategies of distancing in the Jordanian academic discourse. In Arabic language phrase "اذا سمحت", is using to show the negative politeness and usually uses in the formal situations or in the frame of academic discourse.

In Jordanian academic discourse widely used the phrase that we could name a "standard" of negative politeness or must-have phrase of strategy "be conventionally indirect". In the following examples and 
answers of students we can see what is that phrase and how it is used:

$$
\text { لم تتككن من إنهاء مقالتكاك في الوقت المناسب. تريد الإذن بإحضاره في اليوم التالي. }
$$

You did not manage to finish your essay in time. You want the permission to bring it next day.

$$
\text { هل من المكن سأعيده غدًا ، أنا آسف جدًا. }
$$

Could I bring it tomorrow, I am so sorry.

$$
\text { لم تفهم من المادة ما تم شرحه في الفصل ، فأنت تريد من معلك أن يشرح ذلك للك بعد الفصل }
$$

You didn't understand from the material what was explained in class, you want your teacher to explain it to you after class

$$
\text { هل من المكن مساعدنه على فهمه بشكل أفضل؟ }
$$

Could you help him to understand it better?

We could say that it is widely used "هل من المكنن" in the Jordanian academic discourse. This phrase phrase indicates a very formal style of communication, which, on the one hand, indicates a strategy of distancing, and on the other hand, it gives the opportunity to a student or to a professor not to do or do something - give $\mathrm{H}$ the option not to do the act.

As we can see, in Jordanian academic discourse and in American academic discourse the strategy of distancing "be conventionally indirect" is widely used despite of the fact that its two different cultures. This study confirms the thesis that strategy of negative politeness "be conventionally indirect", highlighted by P. Brown and S. Levinson, is universal and is implemented in the language by various means, which, however, may not coincide with the linguistic means of the English language. But another part of the strategies may not be applied in a specific communicative culture, and vice versa, there may be strategies that are characteristic only for a given culture. In this study, we examined strategy "be conventionally indirect" and compared its manifestation in American academic discourse and in Jordanian academic discourse.

\section{CONCLUSION}

Thus, we examined how the negative politeness is implemented in the Arab communicative culture and identified some of its characteristic features. Based on the study, we can conclude that some of the politeness strategies identified by P. Brown and S. Levinson can be applied in communication among Arabs, which confirms their partial universality. Of course, each individual culture is unique and has its own characteristics of polite speech behavior.

This language material does not fully reflect the problem of the study. The material studied by us is not enough to establish all the unique strategies of politeness of the Arab culture, nevertheless, we would like to express the hope that work in this area will continue, since such studies are not very popular with domestic scientists, and this area requires a more complete study. This work may give impetus for further research on politeness and the development of theories of politeness in Arab culture.

\section{REFERENCE LIST}

Alba-Juez, Laura. 2016. Discourse Analysis and Pragmatics: Their Scope and Relation. Russian Journal of Linguistics 20 (4). 43-55.

Brown P., Levinson S. 1987. Politeness: Some universals in language usage. Cambridge.

Grice, H.P. 1975. Logic and conversation. In P. Cole and J.J. Morgan eds., Syntax and Semantics III Speech Acts, New York: Academic Press.

Kecskes, Istvan. 2014. Intercultural Pragmatics. Oxford: Oxford University Press.

Lakoff R. T. 1995. Conversational Implicature. Handbook of Pragmatics. Amsterdam; Philadelphia.

Larina T.V. Category of politeness and communication style: comparison of English and Russian linguocultural traditions. M., 2009.

Larina, T., Leech, G. 2014. Russian Journal of Linguistics. (4). 9-33. 
Leech, Geoffrey N. 1983. Principles of Pragmatics. London / New York: Longman.

Samarah, Abdullah. 2015. Politeness in Arabic Culture. Theory and Practice in Language Studies 5 (10).

Searle, John R. 1969. Speech acts. An essay in the philosophy of language. Cambridge: Cambridge University Press.

Senft, Gunter. 2014. Understanding Pragmatics. London: Routledge.

Vlasyan G.R. Various approaches to the definition of linguistic politeness // Bulletin of Nizhnevartovsk State University. 2010.

Wierzbicka, Anna. 1991/2003. Cross-cultural Pragmatics: the Semantics of Human Interaction. Berlin: Mouton de Gruyter.

Wierzbicka, Anna. 2006b. English. Meaning and Culture. Oxford. Oxford University press. 